\title{
Antibacterial activities of the methanol extracts of seven Cameroonian dietary plants against bacteria expressing MDR phenotypes
}

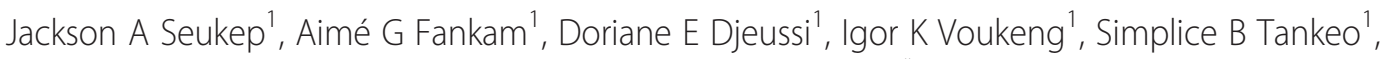
Jaurès AK Noumdem ${ }^{1}$, Antoine HLN Kuete ${ }^{2}$ and Victor Kuete ${ }^{1 *}$

\begin{abstract}
The morbidity and mortality caused by bacterial infections significantly increased with resistance to commonly used antibiotics. This is partially due to the activation of efflux pumps in Gram-negative bacteria. The present work designed to assess the in vitro antibacterial activities of seven Cameroonian dietary plants (Sesamum indicum, Sesamum radiatum, Cinnamomum zeylanicum, Corchous olitorius, Cyperus esculentus, Adansonia digitata, Aframomum kayserianum), against multidrug resistant (MDR) Gram-negative bacteria over expressing active efflux pumps. The standard phytochemical methods were used to detect the main classes of secondary metabolites in the extracts. The antibacterial activities of the studied extracts in the absence or presence of an efflux pump inhibitor (PAßN) were evaluated using liquid microbroth dilution method. The results obtained indicated that apart from the extract of C. esculentus, all other samples contained alkaloids, phenols and polyphenols meanwhile other classes of chemicals were selectively present. The studied extracts displayed antibacterial activities with minimal inhibitory concentrations (MICs) values ranged from 64 to $1024 \mu \mathrm{g} / \mathrm{mL}$ on the majority of the 27 tested microbial strains. The extract of $S$. indicum was active against $77.77 \%$ of the tested microorganisms whilst the lowest MIC value $(64 \mu \mathrm{g} / \mathrm{mL})$ was recorded with that of $A$. kayserianum against E. aerogenes EA294. The results of the present work provide baseline information on the possible used of the tested Cameroonian dietary plants in the treatment of bacterial infections including multi-drug resistant phenotypes.
\end{abstract}

Keywords: Antibacterial activity; Cameroon; Dietary plants; Efflux pumps; Gram-negative bacteria; Multi-drug resistant

\section{Introduction}

The continuous emergence of multidrug-resistant (MDR) bacteria drastically reduces the efficacy of our antibiotic armory, and consequently increases the frequency of therapeutic failure Falagas and Bliziotis (2007). The resistance of bacteria to chemically unrelated antimicrobial agents may be associated with the over-expression of efflux pumps (Poole 2004, Li and Nikaido 2009). In Gram-negative bacteria, many of these efflux pumps belong to the resistance-nodulation-cell division (RND) family of tripartite efflux pumps. Among those efflux pumps, those belonging to the AcrAB-TolC family are

\footnotetext{
* Correspondence: kuetevictor@yahoo.fr

'Department of Biochemistry, Faculty of Science, University of Dschang, Dschang, Cameroon

Full list of author information is available at the end of the article
}

detected in many clinical bacterial isolates and are reported to be a key factor in the expression of the MDR phenotypes (Mallea et al. 2003; Lomovskaya et al. 2004). This efflux pumps mechanism can be blocked by various inhibitors which restore the intracellular concentration as well as the activities of the antibiotics (Chollet et al. 2004; Pagès and Amaral 2009). The scarcity of original synthetic antibiotics has stimulated the search for new antibacterial agents from medicinal plants. This explains our endeavor to evaluate in vitro the antibacterial activities of Cameroonian dietary plants namely the beans of Sesamum indicum, the stem and leaves of Sesamum radiatum, Corchous olitorius and Cyperus esculentus, the bark of Cinnamomum zeylanicum, the fruits of Adansonia digitata and Aframomum kayserianum against Gram-negative bacteria expressing 
MDR phenotypes. The role of efflux pumps in the activity of our plants extracts was also investigated using a previously described efflux pump inhibitor.

\section{Material and methods}

\section{Plant materials and extraction}

The seven edible plants used in this work were purchased from Bafoussam local market, West Region of Cameroon in January 2012. The collected plant samples were the beans of Sesamum indicum, the stem and leaves of Sesamum radiatum, Corchous olitorius and Cyperus esculentus, the bark of Cinnamomum zeylanicum, the fruits of Adansonia digitata and Aframomum kayserianum. The plants were further identified at the National Herbarium (Yaoundé, Cameroon) where voucher specimens were deposited under a reference number (Table 1). The powdered air-dried sample from each plant was extracted with methanol for $48 \mathrm{~h}$ at room temperature. The extract was then concentrated under reduced pressure to give a residue that constituted the crude extract. They were then kept under $4^{\circ} \mathrm{C}$ until further use.

\section{Preliminary phytochemical investigations}

The presence of major secondary metabolite classes, namely, alkaloids, flavonoids, phenols, saponins, tannins, anthocyanins, anthraquinones, sterol, and triterpenes (Table 2) was determined using common phytochemical methods Harbone (1973).

\section{Bacteria strains and culture media}

The studied microorganisms included references (from the American Type Culture Collection) and clinical (Laboratory collection) strains of Escherichia coli, Enterobacter aerogenes, Providencia stuartii, Pseudomonas aeruginosa, Klebsiella pneumoniae, and Enterobacter cloacae (Table 2). They were maintained on agar slant at $4^{\circ} \mathrm{C}$ and subcultured on a fresh appropriate agar plates $24 \mathrm{~h}$ prior to any antimicrobial test. Mueller Hinton Agar (MHA) was used for the activation of bacteria and the Mueller Hinton Broth (MHB) was used for the MIC determinations.

\section{Bacterial susceptibility determinations}

The respective MICs of samples on the studied bacteria were determined by using rapid INT colorimetric assay Mativandlela et al. (2006). Briefly, the test samples were first dissolved in DMSO/MHB. The solution obtained was then added to MHB, and serially diluted two fold (in a 96-well microplate). One hundred microlitres $(100 \mu \mathrm{L})$ of inoculum $\left(1.5 \times 10^{6} \mathrm{CFU} / \mathrm{mL}\right)$ prepared in MHB was then added. The plates were covered with a sterile plate sealer, then agitated to mix the contents of the wells using a shaker and incubated at $37^{\circ} \mathrm{C}$ for 18 hrs. Wells containing MHB, $100 \mu \mathrm{L}$ of inoculum and DMSO at a final concentration of $2.5 \%$ served as negative control (this internal control was systematically added). Chloramphenicol (CHL) was used as reference antibiotic. The MICs of samples were detected after $18 \mathrm{hrs}$ of incubation at $37^{\circ} \mathrm{C}$, following addition $(40 \mu \mathrm{L})$ of $0.2 \mathrm{mg} / \mathrm{mL}$ INT and incubation at $37^{\circ} \mathrm{C}$ for $30 \mathrm{~min}$ Kuete et al. (2008). Viable bacteria reduced the yellow dye to pink. MIC was defined as the lowest sample concentration that prevented this change and exhibited complete inhibition of bacterial growth. For the determination of $\mathrm{MBC}$, he microplates ones were filled by $150 \mu \mathrm{L}$ of MHB without extract of plant; for wells not having received a INT (during the reading of the MIC), $50 \mu \mathrm{L}$ of the contents of the wells corresponding to the concentrations higher or equal to the MIC was taken and introduced into these microplates. These were then incubated during $48 \mathrm{~h}$ à $37^{\circ} \mathrm{C}$ followed by revelation with the INT. All the concentrations to which we did not observe pink coloring were taken as bactericides and smallest of those, was noted as MBC. Samples were tested alone and then, in the presence of $\mathrm{PA} \beta \mathrm{N}$ at $30 \mu \mathrm{g} / \mathrm{mL}$ final concentration.

\section{Results}

\section{Phytochemical composition of the plant extracts}

The results of qualitative analysis showed that all the crude extracts tested, except that for C. esculentus, contained alkaloids, phenols and polyphenols; others phytochemicals classes being selectively detected (Table 3).

\section{Antibacterial activity of the plant extracts}

The various strains and MDR isolates were tested for their susceptibilities to plants extracts and reference antibiotic (chloramphenicol). Chloramphenicol was also tested the presence of PAßN, a well-known efflux pump inhibitor to confirm the role of efflux pumps in the resistance of the studied microorganisms. Assays were performed using the broth microdilution method. The results depicted in Table 4 indicate that the plant extracts exhibited activities depending of bacteria strains, with MICs values ranged from 64 to $1024 \mu \mathrm{g} / \mathrm{mL}$ on the majority of the 27 tested microbial strains. At the tested concentration range ( 8 to $1024 \mu \mathrm{g} / \mathrm{mL}$ ), the extracts which displayed activities against the majority of bacteria strains were those from $S$. indicum (active against $77.77 \%$ of the tested bacteria), C. zeylanicum (70.37\%), S. radiatum (66.66\%), C. olitorius (62.96\%), A. kayserianum (51.85\%), C. esculentus (18,52\%) and A. digitata $(14,81 \%)$. The lowest MIC value $(64 \mu \mathrm{g} / \mathrm{mL})$ was recorded with the extract of $A$. kayserianum against $E$. aerogenes EA294. Other extracts exhibited weak activities against a limited number of strains studied. A keen look of the results of Table 4 also shows that the extract of $S$. indicum displayed the best spectrum of bactericidal 
Table 1 Plants used in the present study and evidence of their activities

\begin{tabular}{|c|c|c|}
\hline $\begin{array}{l}\text { Plants samples, part used and } \\
\text { herbarium voucher number }\end{array}$ & Traditional used & $\begin{array}{l}\text { Known antimicrobial } \\
\text { activities of plants }\end{array}$ \\
\hline $\begin{array}{l}\text { Bombaceae Adansonia } \\
\text { digitata (Fruits) } 42417 / \mathrm{HNC}\end{array}$ & $\begin{array}{l}\text { Febrifuge, antidysentery, antioxydant, analgesic, antidiarrheal } \\
\text { (Kaboré et al. 2011); immunostimulant, hepatoprotective } \\
\text { (Al-Qarawi et al. 2010); anti-small pox, anti-rubella (Wickens 1979). }\end{array}$ & $\begin{array}{l}\text { Aqueous, ethanol and petroleum ether extracts } \mathbf{Q} \text { : Ec (Yagoub 2008). Antiviral } \\
\text { activity against Vi, Vhs (Vimalanathan and Hudson 2009), Vp (Anani et al. 2000) }\end{array}$ \\
\hline
\end{tabular}

Cyperaceae Cyperus esculentus (Fruits) 14977/SRFC

Pedaliaceae Sesamum indicum

(Beans) 42898/HNC

Lauraceae Cinnamomum

zeylanicum. (Bark) Blume 22309/SRFC

$(/)^{b}$

Liniment laxative, emollient (Kokate et al. 2005); lenitif, anticonstipation,

anti-carries (Awobajo et al. 2009), antitumor (Xu et al. 2010), hepatoprotective

(Kumar et al. 2011), hypoglycemic (Nakano and Kwak 2006).

Digestive disorders, anti dysentery, laxative.

Isolated compounds (Cinnamaldehyde and Eugenol) from essential oil showed an activity: against PI (Gende et al. 2008) ; antibacterial activities against multi-resistant Gram-negative bacteria (Pa, PS, Kp, EC., Ea, Ecl) (Voukeng et al. 2012)

Tiliaceae Corchous olitorius

(Stem and leaves) 14725/SRFC

Gonorrhoea, cystitis chronic, analgesic, febrifuge, antitumor, anti-

inflammatory (Zacharia et al. 2006; Ramadevi and Ganapaty 2011),

diuretic, cardiotonic (Ramadevi and Ganapaty 2011).

Methanol, chloroform and petroleum ether extracts. S: Bs, Pa, Sm. F: Sa, Ec, La, ML, San, Sau, Kp. M: Ea, Pv. Q: Rs, Ca (Ramadevi and Ganapaty 2011), Ec Zacharia et al. (2006) Sau Bp, St, Sb, Ss, Sd,Pa, Kp, Ec,Vc Pal et al. (2006).

Pedaliaceae Sesamum radiatum Schum et Thom (Stem and leaves)

Antirhume, anticatarrate, against ocular pains and cutaneous eruptions 8797/SRFC

(Bankole et al. 2007), antimicrobial (Shittu et al. 2007; Osibote et al. 2010).

Methanol and ethanol extracts S: Ca (Shittu et al. 2007). Essential

oil :Q: Csp. Ec, Ec ATCC 25922, Kp, Pm, Pa, Sal, Sa, Sm Tane et al. (2005).

Isolated compound Aframodial from this plant showed an activity: S : Sc, Sp,Ha, Cu, Scl, Pc.; M : Mm, Rc, An, Sau, Bs. F : Ec, Pa (Ayafor et al. 1994).

Zingiberaceae Aframomum kayserianum Anti-mumps, dysmenorrhoeas, vermifuge (Tane et al. 2005).

(Fruits) K.schum 18884/SRFC

S: SC, Sp,Ha, Cu, Scl, PC.; M : Mm, RC, An, Sau, Bs. F : EC, Pa (Ayafor et al. 1994).

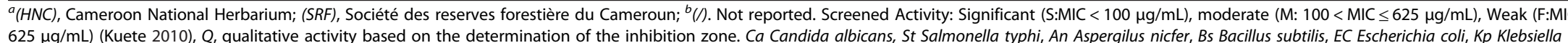
$625 \mu \mathrm{g} / \mathrm{mL}$ ) (Kuete 2010), Q, qualitative activity based on the determination of the inhibition zone. Ca Candida albicans, St Salmonella typhi, An Aspergilus nicfer, Bs Bacillus subtilis, EC Escherichia coli, Kp Klebsiella pneumoniae, Pa Pseudomonas aeruginosa, Pvt Proteus vulgaris, Sau Staphylococcus aureus, Cu Candida utilis, Sc Saccharomyces cereviciae, Sm Streptococeus mutans, Sa Streptococcus aeogingsa, La Lactobacillus acidophilus, Pm Proteus mirabilis, Sal Staphylococcus albus, Sma Serratia marcescens, Sp Schizosaccharomyces pombe, Ha Hansenula anomala, Scl Sclerotinia libertiana, PC Penicillim crustasum, Mm Mucor mucedo, Rc Rhizopus chinensis, Ecl Enterobacter cloacae, PS Providencia stuartii, PI Paenibacillus larvae, Vhs herpes simplex virus, Vp Virus of poliomyelitis, VI Influenza. Virus. 
Table 2 Bacterial strains and features

\begin{tabular}{|c|c|c|}
\hline Bacteria & Features & References \\
\hline \multicolumn{3}{|l|}{ Escherichia coli } \\
\hline АTCC8739 & Reference strain of Escherichia coli & \\
\hline ATCC10536 & Reference strain of Escherichia coli & \\
\hline W3110 & Wild-type E. coli K-12 & (Bagliomi et al. 2003) \\
\hline MC4100 & Wild-type E. coli K-12, KAN ${ }^{R}$ & (Martina 2002) \\
\hline AG100A & $A G 100 \triangle a c r A B:: K A N^{R}$ & $\begin{array}{l}\text { (Monks et al. 1992; Okusu et al. 1996; } \\
\text { Pradel and Pagès 2002) }\end{array}$ \\
\hline AG100Atet & $\triangle \mathrm{acr} A \mathrm{~B}$ mutant $\mathrm{AG} 100$, owing acrF gene markedly overexpressed; $\mathrm{TET}^{R}$ & Monks et al. (1992) \\
\hline AG102 & $\triangle \mathrm{acr} A B$ mutant $\mathrm{AG} 100$ & Chevalier et al. (2000) \\
\hline AG100 & Wild-type E. coli K-12 & Lorenzi et al. (2009) \\
\hline \multicolumn{3}{|l|}{ E. aerugenes } \\
\hline ATCC13048 & Reference strain & \\
\hline EA294 & EA $289 \triangle$ acrAB: KAN ${ }^{R}$ & (Pradel and Pagès 2002; Ghisalberti et al. 2005) \\
\hline CM64 & $\begin{array}{l}\text { CHLR resistant variant obtained from ATCC13048 over-expressing } \\
\text { the AcrAB pump }\end{array}$ & Ghisalberti et al. (2005) \\
\hline EA298 & EA 289 tolC::KAN ${ }^{R}$ & (Pradel and Pagès 2002; Ghisalberti et al. 2005) \\
\hline EA27 & $\begin{array}{l}\text { Clinical MDR isolate exhibiting energy-dependent norfloxacin } \\
\text { and chloramphenicol efflux with } K A N^{R} \text { and } A M P^{R} \text { and } N A L^{R} \text { and } S T R^{R} \text { and } T E T^{R}\end{array}$ & (Mallèa et al. 2002; Ghisalberti et al. 2005) \\
\hline EA289 & KAN sensitive derivative of EA27 & Ghisalberti et al. (2005) \\
\hline \multicolumn{3}{|l|}{$\begin{array}{l}\text { Klebsiella } \\
\text { pneumoniae }\end{array}$} \\
\hline ATCC11296 & Reference strain & \\
\hline Kp55 & Clinical MDR isolate, TET $^{R}$,AMP ${ }^{R}$, ATM $^{R}$, and $\mathrm{CEF}^{R}$ & Chevalier et al. (2000) \\
\hline Kp63 & Clinical MDR isolate, $\mathrm{TET}^{R}, \mathrm{CHL}^{\mathrm{R}}, \mathrm{AMP}^{\mathrm{R}}$, and $\mathrm{ATM}^{\mathrm{R}}$ & Fredrickson et al. (2004) \\
\hline K2 & Klebsiella pneumonia AcrAB-TolC & Laboratory collection \\
\hline K24 & Klebsiella pneumoniae AcrAB-Tolc & \\
\hline \multicolumn{3}{|l|}{$\begin{array}{l}\text { Pseudomonas } \\
\text { aeruginosa }\end{array}$} \\
\hline PA01 & Reference strain & \\
\hline PA124 & MDR clinical isolate & Lorenzi et al. (2009) \\
\hline \multicolumn{3}{|c|}{ Providencia stuartii } \\
\hline ATCC29916 & Reference strain & \\
\hline PS2636 & Clinical MDR isolate, AcrAB & Laboratory collection \\
\hline PS299645 & Clinical MDR isolate, AcrAB & \\
\hline \multicolumn{3}{|l|}{$\begin{array}{l}\text { Enterobacter } \\
\text { cloacae }\end{array}$} \\
\hline BM47 & Enterobacter cloacae AcrAB-Tolc & \\
\hline ECCI69 & Enterobacter cloacae AcrAB-TolC & \\
\hline BM67 & Enterobacter cloacae AcrAB-TolC & \\
\hline
\end{tabular}

$\mathrm{AMP}^{\mathrm{R}}, \mathrm{ATM}^{\mathrm{R}}, \mathrm{CEF}^{\mathrm{R}}, \mathrm{CFT}^{\mathrm{R}}, \mathrm{CHL}^{\mathrm{R}}, \mathrm{FEP}^{\mathrm{R}}, \mathrm{KAN}^{\mathrm{R}}, \mathrm{MOX}^{\mathrm{R}}, \mathrm{NAL}^{\mathrm{R}}, \mathrm{NOR}^{\mathrm{R}} \mathrm{STR}^{\mathrm{R}}$, and TET ${ }^{\mathrm{R}}$ Resistance to ampicillin, aztreonam, cephalothin, cefadroxil, chloramphenicol, cefepime, kanamycin, moxalactam, streptomycin, and tetracycline; MDR multidrug resistant., OMPF and OMPC Outer Membran Protein F and C respectively. AcrABTolC efflux pump AcrAB associate to TolC porine, Pa Pseudomonas aeruginosa.

effect with a ratio $\mathrm{MBC} / \mathrm{MIC} \leq 4$ on 6 bacterial strains, followed by that of $S$. radiatum $(2 / 27)$ and those of $C$ zeylanicum, C. olitorius, A. kayserianum (1/27). Only the extract of $A$. digitata did not present any bactericidal activity.
Role of efflux pumps in susceptibility of Gram-negative bacteria to the tested plants extracts

The various strains and MDR isolates were also tested for their susceptibility to CHL in the presence of PA $\beta N$. 
Table 3 Parts used, extraction yields, physical aspect and phytochemical composition of the plant extracts

\begin{tabular}{|c|c|c|c|c|c|c|c|}
\hline $\begin{array}{l}\text { Extracts } \\
\text { Parts used }\end{array}$ & $\begin{array}{c}\text { S. radiatum } \\
\text { Stem and leaves }\end{array}$ & $\begin{array}{c}\text { C. zeylanicum } \\
\text { Bark }\end{array}$ & $\begin{array}{c}\text { C. olitorius } \\
\text { Stem and leaves }\end{array}$ & $\begin{array}{l}\text { S. indicum } \\
\text { Beans }\end{array}$ & $\begin{array}{l}\text { A. kayserianum } \\
\text { Fruits }\end{array}$ & $\begin{array}{l}\text { A. digitata } \\
\text { Fruits }\end{array}$ & $\begin{array}{l}\text { C. esculentus } \\
\text { Fruits }\end{array}$ \\
\hline Yield* (\%) & 6.67 & 5.65 & 4.81 & 4.87 & 4.95 & 3.40 & 15.21 \\
\hline Alkaloids & + & + & + & + & + & + & - \\
\hline Anthocyanins & - & + & - & - & + & - & - \\
\hline Anthraquinones & - & - & - & + & - & - & - \\
\hline Flavonoids & + & - & - & - & - & + & - \\
\hline Phenols & + & + & + & + & + & + & - \\
\hline Tannins & + & - & + & - & + & - & - \\
\hline Triterpenes & - & + & - & + & + & + & + \\
\hline Sterols & + & - & + & + & - & + & + \\
\hline Saponins & - & - & + & + & + & + & + \\
\hline
\end{tabular}

(+): Present; (-): Absent; ${ }^{*}$ yield calculated as the ratio of the mass of the obtained methanol extract/mass of the plant powder.

As shown in Table 4, PAßN improved the activity of CHL to all studied bacteria.

\section{Discussion}

The extract from $A$. digitata, others extracts exhibited antibacterial activities against at least one of the tested bacteria. The differences in antibacterial activities were noted between the various extracts and could be related to the differences in their phytochemical composition as shown in Table 2. Except in the extract of C. esculentus, the alkaloids, phenols and polyphenols were detected in all extracts. The antibacterial activities of many molecules belonging to these classes of compounds were shown (Cowan 1999; Kuete et al. 2009). Sharma and Singh (2011) also associated the antibacterial activities of the medicinal plants to the presence of flavonoids, tannins and alkaloids. It should however be mentioned that the detection of the bioactive phytochemical classes in a plant is not a guarantee for any biological property, as this will depend on the types of compounds, as well as their concentrations and possible interaction with other constituents.

Alkaloids, phenols, sterols, polyphenols, triterpenes, anthraquinones and saponins were detected in the extract of S. indicum. The presence of the anthocyanins and the flavonoids in this plant was previously reported Awobajo et al. (2009), though such classes of chemicals were not detected in this work. This could be explained by fact that the presence of the secondary metabolites in a plant depend on the environmental factors such as climate, chemical nature of the ground in which plant grow, the period of harvest, conditions of drying and extraction method Bruneton (1999). To the best of our knowledge, no antibacterial activity of this plant was shown up to now, but presence of the various classes of secondary metabolites could explain its activity on majority of tested strains obtained in this work. In addition the antibacterial activities of the essential oil of S. radiatum (Shittu et al. 2006, Shittu et al. 2007; Konan et al. 2008).

Voukeng and collaborators (2012) documented the antibacterial activities of methanol extract of the sheets of C. zeylanicum against MDR Gram-negative bacteria used in this work. The presence of the phenolic compounds detected in thebark of this plant could explain its activities. Significantantibacterial activities of the methanol extract of $C$. olitorius were shown against the Gram-positive bacteria Pal et al. (2006). Also, the roots of this plant showed a significant antibacterial activity Ramadevi and Ganapaty (2011). The antibacterial activities of this plant as shown in this work provide therefore additional data on its antimicrobial potentials. Plants of the genus Aframomum are known for their antibacterial activities, and this has been assigned to the presence of terpenoids such as aframodial Ayafor et al. (1994). This could also explain the activity observed with the extract of $A$. kayserianum in the present work. Several former studies showed the presence of the terpenoids, phenolic and alkaloids in the extract of A. digitata (Wickens 1979; Chadare et al. 2009). The aqueous, ethanol, and petroleum-ether extracts of this plant have shown an antibacterial activity against $E$. coli Yagoub (2008). However, we observed a weak antibacterial activity of this plant. The extract of $C$. esculentus contains less secondary classes of metabolites. Only sterols, triterpenes and saponins were detected. To the best of our knowledge, the antibacterial of this plant is being reported for the first time. Generally, the weak antibacterial activity observed with the majority of the extracts could be explained by the fact that bacterial strains used are MDR phenotypes expressing active efflux pumps Cattoir (2004), as shown with the increase of the activity of CHL in the 
Table 4 MIC, MBC and MBC/MIC ratios of plants extracts and CHL on the studied bacterial species

\begin{tabular}{|c|c|c|c|c|c|c|c|c|c|}
\hline \multirow[t]{2}{*}{ Tested bacteria } & \multicolumn{8}{|c|}{ Extracts and antimicrobial parameters (MIC and $\mathrm{MBC}$ in $\mu \mathrm{g} / \mathrm{mL}$ ) } & \multirow[b]{2}{*}{$\mathrm{CHL}+\mathrm{P} \beta \mathrm{BN}$} \\
\hline & S. radiatum & C. zeylanicum & C. olitorius & S. indicum & A. kayserianum & A. digitata & C. esculentus & $\mathrm{CHL}$ & \\
\hline \multicolumn{10}{|l|}{ E. coli } \\
\hline ATCC8739 & $1024(-)$ & - & - & - & - & - & - & $8(512)$ & 4 \\
\hline ATCC10536 & $512(-)$ & - & $1024(-)$ & $512(-)$ & - & $512(-)$ & $512(512)$ & $4(128)$ & 1 \\
\hline W 3110 & - & $1024(-)$ & - & $1024(-)$ & $512(-)$ & - & - & $4(32)$ & 1 \\
\hline MC4100 & - & $512(512-)$ & $1024(-)$ & - & $1024(-)$ & - & - & $128(512)$ & 8 \\
\hline AG100 A & - & $512(-)$ & $128(512)$ & $512(512)$ & $1024(-)$ & - & $256(-)$ & $4(64)$ & 0.5 \\
\hline AG100Atet & $1024(-)$ & $512(-)$ & $1024(-)$ & $512(-)$ & $512(-)$ & - & $1024(-)$ & $64(8)$ & 8 \\
\hline AG102 & $1024(-)$ & $512(-)$ & $1024(-)$ & $1024(-)$ & $1024(-)$ & - & - & $32(512)$ & 8 \\
\hline AG100 & - & $1024(-)$ & $512(-)$ & $512(-)$ & - & - & - & $4(128)$ & $<4$ \\
\hline \multicolumn{10}{|l|}{ E. aerogenes } \\
\hline ATCC13048 & - & - & $512(-)$ & $1024(-)$ & - & - & - & $8(32)$ & 4 \\
\hline EA294 & - & $256(-)$ & - & - & $64(512)$ & - & - & $32(512)$ & 8 \\
\hline CM64 & $1024(-)$ & $1024(-)$ & $-(-)$ & $1024(-)$ & - & - & - & $128(-)$ & 64 \\
\hline EA298 & $1024(-)$ & $512(-)$ & $1024(-)$ & 1024 (1024) & $1024(-)$ & $256(-)$ & $512(-)$ & $256(-)$ & 64 \\
\hline EA27 & - & - & $1024(-)$ & $256(1024)$ & $512(-)$ & - & - & - & 32 \\
\hline EA289 & $1024(-)$ & $1024(-)$ & - & $1024(-)$ & - & - & - & $256(-)$ & 64 \\
\hline \multicolumn{10}{|l|}{ K. pneumoniae } \\
\hline ATCC11296 & $512(-)$ & $256(-)$ & - & $512(-)$ & - & - & - & $8(256)$ & 4 \\
\hline KP55 & $512(-)$ & $512(-)$ & $1024(-)$ & $512(512)$ & 1024 (1024) & - & - & $4(128)$ & 1 \\
\hline KР63 & $1024(-)$ & $1024(-)$ & $1024(-)$ & $1024(-)$ & $1024(-)$ & - & - & $128(-)$ & 32 \\
\hline K2 & $1024(-)$ & $1024(-)$ & $512(-)$ & $256(256)$ & - & $1024(-)$ & - & $4(128)$ & 1 \\
\hline K24 & - & $512(-)$ & $1024(-)$ & $256(-)$ & $512(-)$ & - & - & $32(512)$ & 32 \\
\hline \multicolumn{10}{|l|}{ P. aeruginosa } \\
\hline PA01 & $1024(-)$ & - & - & - & - & - & - & $32(256)$ & 8 \\
\hline PA124 & $1024(-)$ & - & - & - & - & - & - & $64(512)$ & 16 \\
\hline \multicolumn{10}{|l|}{ P. stuartii } \\
\hline ATCC29916 & $256(1024)$ & $256(-)$ & - & - & $512(-)$ & - & - & $4(32)$ & 2 \\
\hline PS2636 & $1024(-)$ & - & $512(-)$ & $512(1024)$ & $1024(-)$ & - & - & $4(64)$ & 2 \\
\hline PS299645 & - & $512(-)$ & $1024(-)$ & $1024(-)$ & - & $256(-)$ & $1024(-)$ & $16(64)$ & 4 \\
\hline \multicolumn{10}{|l|}{ E. cloacae } \\
\hline BM47 & $1024(-)$ & $1024(-)$ & $1024(-)$ & $1024(-)$ & - & - & - & $256(-)$ & 16 \\
\hline ECCI69 & $1024(-)$ & - & $512(-)$ & $1024(-)$ & - & - & - & $256(-)$ & 16 \\
\hline BM67 & 512512 & $512(-)$ & - & $1024(-)$ & $1024(-)$ & - & - & $512(-)$ & 16 \\
\hline
\end{tabular}

$(-):>1024 \mu \mathrm{g} / \mathrm{mL}$ for the extracts and > $512 \mu \mathrm{g} / \mathrm{mL}$ for chloramphenicol and non given MBC/MIC. NT: not tested. (): MBC in $\mu \mathrm{g} / \mathrm{m}$.

presence of PAßN (Table 4). It was demonstrated that efflux pumps decrease the intracellular concentration of chemicals and consequently their activities (Bambeke and Pagès 2010; Kuete 2010). These efflux pumps can be blocked in a competitive way or not, by an efflux inhibitor, which restore therefore not only intracellular concentration, but also the activity of antibiotics (Pagès and Amaral 2009; Kuete 2010). Finally, the results obtained with the studied plants are encouraging not only because we are dealing with MDR bacteria, but also the fact investigated plant materials are food plants which are relatively non toxic.

\section{Conclusion}

The results of the present work provide baseline information on the possible used of the tested Cameroonian dietary plants in the treatment of bacterial infections including MDR phenotypes. 


\section{Competing interests}

The authors declare that they have no competing interests.

\section{Authors' contributions}

AJS, AGF, DED, JAKN, IKV, SBT and AHLN carried out the study; VK designed the experiments and supervised the work; AGF and AJS wrote the manuscript; VK provided the bacterial strains; All authors read and approved the final manuscript.

\section{Author details}

'Department of Biochemistry, Faculty of Science, University of Dschang, Dschang, Cameroon. 'Department of Organic Chemistry, Faculty of Science, University of Dschang, Dschang, Cameroon.

\section{Received: 9 May 2013 Accepted: 29 July 2013}

Published: 31 July 2013

\section{References}

Al-Qarawi AA, Al-Damegh MA, El-Mougy SA (2010) Hepatoprotective Influence of Adansonia digitata Pulp. Journal of Herbs Spices and Medicinal Plants 10:1-6

Anani K, Hudson JB, Souzal C, Akpagana K, Tower GHN, Amason JT, Gbeassor M (2000) Investigation of medicinal plants of Togo for antiviral and antimicrobial activities. Pharmceut Biol 38:40-45

Awobajo FO, Omorodion-Osagie E, Olatunji-Bello II, Adegoke OA, Adeleke TL (2009) Acute oral toxicity and phytochemistry of some West African medicinal plants. Nigerian Quarterly Journal of Hospital Medicine 19:320-329

Ayafor JF, Tchuendem MH, Nyasse AB, Tillequin AH (1994) Aframodial and other bioactive diterpenoids from Aframomum species. Appl Chem 66:2327-2330

Bagliomi P, Liberatori S, Pallini V, Marri L (2003) Proteome analysis of Escherichia coli W3110 expressing an heterogenous sigma factor. Proteomics 3:1060-1065

Bambeke F, Pages J-M, Lee VJ (2010) Inhibitor of bacterial efflux pumps as adjuvants in antibacterial therapy and diagnostic tools for detection of resistance by efflux. Frontier in Anti-Infective Drug Discovery 1:00-34

Bankole MA, Shittu TA, Ahmed MN, Bankole RK, Shittu T, Kpela AOA (2007) Synergistic antimicrobial activities of phytoestrogens in crude extract of two sesame species against some common microorganisms. Afr J Trad Compl Altern Med 4:427-433

Bruneton J (1999) Plantes Médicinales, Pharmacognosie, phytochimie. Tec et Doc, Paris

Cattoir V (2004) Pompes d'efflux et résistance aux antibiotiques chez les bactéries. Pathol Biol 52:607-616

Chadare FJ, Linnemann AR, Hounhouigan JD, Nout MJR, Van B (2009) Baobab food products: a review on their composition and nutritional value. Critical Review in Food Science and Nutrition 49:254-274

Chevalier J, Pagès J-M, Eyraud A, Malléa M (2000) Membrane permeability modifications are involved in antibiotic resistance in Klebsiella pneumoniae. Biochem Biophys Res Commun 274:496-499

Chollet R, Chevalier J, Bryskier A, Pagès J-M (2004) The AcrAB-TolC pump is involved in macrolide resistance but not in telithromycin efflux in Enterobacter aerogenes and Escherichia coli. Antimicrob Agents Chemother 48:3621-3624

Cowan MM (1999) Plant products as antimicrobial agents. Clin Microb Rev 12:564-582

Falagas ME, Bliziotis IA (2007) Pandrug-resistant Gram-negative bacteria (2007) the dawn of the post-antibiotic era. Int J Antimicrob Ag 29:630-636

Fredrickson J, Zachara J, Balkwill D (2004) Geomicrobiology of high-level nuclear waste-contaminated vadose sediments at the Hanford site, Washington state. Appl Environ Microbiol 70:4230-4241

Gende LB, Ignazio F, Rosalia F, Martin JE (2008) Antimicrobial activity of cinnamon (Cinnamomum zeylanicum) essential oil and its main components against Paenibacillus larvae from Argentine. Bull Insectology 61:1-4

Ghisalberti D, Masi M, Pagès J-M, Chevalier J (2005) Chloramphenicol and expression of multidrug efflux pump in Enterobacter aerogenes. Biochem Biophys Res Commun 328:1113-1118

Harbone JB (1973) Phytochemical methods: A guide to modern techniques of plant analysis. Chapman and Hall, London

Kaboré D, Hagrétou S, Bréhima D, Compaoré CS, Dicko MH, Mogens J (2011) A review of baobab (Adansonia digitata) products effect of processing techniques, medicinal properties and uses. African Journal of Food Science 5:833-844

Kokate C, Purohit A, Gokhale S (2005) Pharmacognosy, 17th edn. New Delhi, Pune

Konan AB, Datte JY, Yapo PA (2008) Nitric oxide pathway-mediated relaxant effect of aqueous sesame leaves extract (Sesamum radiatum) in the guinea pig isolated aorta smooth muscle. BMC Complement Alter Med 8:23
Kuete V, Fozing DC, Kapche WFGD, Mbaveng AT, Kuiate JR, Ngadjui BT, Abegaz BM (2009) Antimicrobial activity of the methanolic extract and compounds from Morus mesozygia stem bark. J Ethnopharmacol 124:551-555

Kuete V, Ngameni B, Simo CCF, Tankeu RK, Ngadjui BT, Meyer JJM, Lall N, Kuiate JR (2008) Antimicrobial activity of the crude extracts and compounds from Ficus chlamydocarpa and Ficus cordata (Moraceae). J Ethnopharmacol 120:17-24

Kuete $\mathrm{V}$, Ngameni B, Tangmouo JG, Bolla J-M, Alibert-Franco S, Ngadjui BT, Pagès J-M (2010) Efflux pumps are involved in the defence of Gram-negative bacterial against the natural products isobavachalcone and diospyrone. Antimicrob ag chemother 54:1749-1752

Kuete V (2010) Potential of Cameroonian plants and derived products against microbial infections: a review. Planta Med 76:1-13

Kumar M, Anjoo K, Sidhraj S (2011) Hepatoprotective activity of Sesamum Indicum Linn. against Ccl4-induced hepatic damage in rats. International Journal of Pharmaceutical and Biological Archives 2:710-715

Li XZ, Nikaido H (2009) Efflux-mediated drug resistance in bacteria: an update. Drugs 69:1555-1623

Lomovskaya OMS, Warren A, Lee J, Galazzo R, Fronko M, Lee J, Blais J, Cho D, Chamberland S, Renau T, Leger R, Hecker S, Watkins W, Hoshino K, Ishida H, Lee VJ (2004) Identification and characterization of inhibitors of multidrug resistance efflux pumps in Pseudomonas aeruginosa: novel agents for combination therapy. Antimicrob Ag Chemother 45:105-116

Lorenzi V, Muselli A, Bernadini AF, Berti L, Pages J-M (2009) Geraniol restores antibiotic activities against multidrugs resistant isolates from Gram-negative species. Antimicrob Ag Chemother 53:2209-2211

Mallèa M, Chevalier J, Eyraud A, Pagès J-M (2002) Inhibitors of antibiotic efflux pumps in resistant Enterobacter aerogenes strains. Biochem Biophys Res Commun 293:1370-1373

Mallea M, Mahamoud A, Chevalier J, Alibert-Franco S, Brouant P, Barbe J, Pages JM (2003) Alkylaminoquinolines inhibit the bacterial antibiotic efflux pump in multidrug-resistant clinical isolates. Biochemical Journal 376:801-805

Martina AW (2002) Identification and characterization of sulfur-regulated gene in Escherichia coli MC4100, A dissertation submitted to the Swiss Institute of technology. degree of Doctor of Natural Sciences, Zurich

Mativandlela SPN, Lall N, Meyer JJM (2006) Antibacterial, antifungal and antitubercular activity of (the roots of) Pelargonium reniforme (CURT) and Pelargonium sidoides (DC) (Geraniaceae) root extracts. S Afr J Bot 72:232-237

Monks TJ, Hanzlik RP, Cohen GM, Ross D, Graham DG (1992) Quinone chemistry and toxicity. Toxicol Appl Pharmacol 112:2-16

Nakano D, Kwak CJ (2006) Sesamine metabolites induce an endothelial nitric acid dependent vasorelaxation. J Pharmacol Exp Ther 318:328-335

Okusu H, Ma D, Nikaido HD (1996) AcrAB efflux pump plays a major role in the antibiotic resistance phenotype of Escherichia coli multiple-antibiotic-resistance Mar. mutants. J Bacteriol 178:306-308

Osibote EAS, Ogunlesi M, Okiei W, Asekun T, Familani OB (2010) Assessment of antimicrobial activity of the essential oil from the stem powder of Cissus populnea and the leaves of Sesamum radiatum, herbal medications for male infertility factor. J Med Plants Res 4:14-20

Pagès J-M, Amaral L (2009) Mechanisms of drug efflux and strategies to combat them: challenging the efflux pump of Gram-negative bacteria. Biochim Biophys Acta 1794:826-833

Pal D, Mandal GP, Padhiari SA (2006) Antibacterial activity of Cuscuta reflexa stem and Corchous olitorius seed. Fitoterapia 77:589-591

Poole K (2004) Efflux-mediated multiresistance in Gram-negative bacteria. Clin Microbiol Infect 10:12-26

Pradel E, Pagès J-M (2002) The AcrAB-TolC efflux pump contributes to multidrug resistance in the nosocomial pathogen Enterobacter aerogenes. Antimicrobl Ag Chemother 46:2640-2643

Ramadevi D, Ganapaty S (2011) Antimicrobial activity of Corchous olitorius L. Pharmacology online 2:1303-1308

Sharma SK, Singh AP (2011) Antimicrobial investigations on rhizomes of Cyperus rotundus Linn. Der Pharmacia Lettre 3:427-431

Shittu L, Bankole MA, Ahmed T, Bankole MN, Shittu RK, Saalu CL, Ashiru OA (2007) Antibacterial and antifungal activities of essential oils of crude extracts of Sesame Radiatum against some common pathogenic microorganisms. Iranian Journal of Pharmacology and Therapeutics 6:165-170

Shittu LAJ, Bankole MA, Ahmed T, Aile K, Akinsanya MA (2006) Differential antimicrobial activity of the various crude leaves extracts of Sesamum radiatum against some common pathogenic microorganisms. Scientific Research and Essays 1:108-111 
Tane P, Tatsimo SD, Ayimele GA, Conolly JD (2005) Bioactive metabolites from Afromomum species. 11th NAPRECA Symposium Book of Proceedings, Antananarivo: Madagascar, pp 214-223

Vimalanathan S, Hudson JB (2009) Multiple inflammatory and antiviral activities in Adansonia digitata (Baobab) leaves, fruits and seeds. Journal of Medicinal Plants Research 3:576-582

Voukeng I, Kuete V, Dzoyem JP, Fankam AG, Noumedem JA, Kuiate JR (2012) Pages J-M (2012) antibacterial and antibiotic-potentiation activities of the methanol extract of some Cameroonian spices against Gram-negative multidrug resistant phenotypes. BMC Res Notes 5:299

Wickens GE (1979) The uses of the baobab (Adansonia digitata L.) in Africa. In: Kunkel G (ed) Taxonomic aspects of African economic botany. A.E.T.F.A.T, Las Palmas de Gran Canaria, pp 27-34, 250 pp

Xu H, Yong-ping WZ, Qing H (2010) In vitro antitumour activity of Sesamum indicum Linn flower extracts. Trop J Pharmaceut Res 9:455-462

Yagoub S (2008) Antimicrobial activity of Tamarindus indica and Adansonia digitata extracts against $E$. coli isolated from urine and water specimens. Research. Journal of Microbiology 3:193-197

Zacharia ZA, Somchit MN, Zaiton H, Mat AM, Sulaiman MR, Farah WO, Nazaratulmawarina R, Fatimah CA (2006) The in vitro antibacterial activity of Corchous olitorius extracts. International Journal of Pharmacology 2:213-215

doi:10.1186/2193-1801-2-363

Cite this article as: Seukep et al: Antibacterial activities of the methanol extracts of seven Cameroonian dietary plants against bacteria expressing MDR phenotypes. SpringerPlus 2013 2:363.

\section{Submit your manuscript to a SpringerOpen ${ }^{\circ}$ journal and benefit from:}

- Convenient online submission

- Rigorous peer review

- Immediate publication on acceptance

- Open access: articles freely available online

- High visibility within the field

- Retaining the copyright to your article

Submit your next manuscript at $>$ springeropen.com 